the kindness of the Clifton Colliery Co., inspected the coal mine at Clifton Colliery, and then went on to Thurgarton. The other section accompanied Prof. Carr to the brickyard on the west side of Bulwell, where a section of the Middle Permian Marls, about $30 \mathrm{ft}$. thick, was seen resting upon the Lower Magnesian Limestone. The Permian Marls passed upwards without apparent break into the Lower Mottled Sandstone of the Trias. A quarry a little to the north of the brickyard was next visited, where the Lower Magnesian Limestone, about $30 \mathrm{ft}$. thick was seen. The party next drove to Kimberley to examine the section exposed in the excavation for the Great Northern Railway Station. This section shows at the top the Lower Magnesian Limestone resting upon the Marl Slate, at the base of which is a hard compact breccia about $3 \mathrm{ft}$. thick, composed of fragments principally of Carboniferous rocks in a calcareous matrix. This breccia forms the base of the Permian in Northamptonshire, and rests with a marked unconformity upon the upturned edges of the Middle Coal Measures.

After arrival at Thurgarton, both sections walked a short distance to the borehole which is being put down by Messrs. Barber, Walker \& Co., as a trial for coal. The cores from the Trias and Permian formations were inspected by the party, and the boring machinery was explained by Mr. Coke. Mr. Shipman met the party and made a few remarks on the geology of the district.

The President thanked Messrs. Barber, Walker \& Co., on behalf of those present, for the permission to visit the borehole ; and Mr. Coke for the assistance he had rendered in organising the supplementary excursions.

\title{
EXCURSION TO WELDON, DENE, AND GRETTON.
} Saturday, April 29Th, 1899 .

Director: Beeby Thompson, F.C.S., F.G.S. Excursion Secretary : Bedford McNeILl, A.R.S.M., F.G.S.

(Report by ThE DIRECTOR)

THE excursion was arranged in order to examine the whole of the strata comprising the Inferior Oolite in the area embraced. The sequence of beds will be best seen on reference to the accompanying diagram of comparative sections.

Weldon and Corby Brickworks was the first section visited. The clay worked here belongs to the upper part of the Upper Lias, and embraces a part of two zones, the Upper Leda-ovumBeds (Jurensis zone of Thompson; Lilli hemera of S.S. Buckman), and the Middle Leda-ovum-Beds (a part of the A.communis zone). There is a false junction between the Upper Lias Clay and the Northampton Sand owing to the slipping of the NOVEMBER, 1899.] 
latter over the former; also, it was noted that the clay itself was thrown into a sharp fold, a result due, no doubt, to the slipping of the clay itself towards the valley.

Only a few fossils were obtained, but the visitors were shown the head of a Teleosaurus that had been found quite recently. A few years back a fairly complete skeleton of an Ichthyosaurus, $23 \mathrm{ft}$. in length, was found here, and is now in the Northampton Museum.

The Ironstone workings near the brickworks, and close to the village of Corby, were next examined, and attention was particularly directed to the Chalky Boulder Clay (A) with large erratics and scratched blocks, resting on the Lower Estuarine Beds (5 to 8 ).* The Estuarine Beds are very variable in character, alternations of vertical and horizontal carbonaceous markings being frequent. In No. 6, horizontally bedded carbonaceous matter occurs near the bottom. In No. 7 , the first foot or so is a good clay with very numerous, black, horizontal lines of carbonaceous matter; below this, however, the bed is more sandy and the carbonaceous matter irregularly disposed.

Weldon.-Some disused ironstone workings to the north of Weldon Grange were next visited, in order to observe the continuity of the various beds seen at Corby, and the changes in some of them. The whole section embraced beds 4 to 9 . Here, as at Corby, there is an irregular junction between beds 7 and 8 . The total thickness of the exposed beds is very near to the total thickness of the corresponding beds at Corby. A considerable N. to S. fault near here lets down all the beds to the east, so that the ironstone in that direction is too deep to work, even if it were suitable.

Great Weldon Stone Quarries. - The noted freestone quarries at Great Weldon, owned by Lord Winchilsea, were next inspected, by the courtesy of Mr. John Rooke, under the guidance of the foreman of the works. The stone varies a good deal, and much has to be wasted, but when well selected it furnishes a very beautiful stone for ornamental work, of a. pleasing colour and good wearing qualities. The total thickness is from 20 to $25 \mathrm{ft}$. (For full description see Sharp, "Oolites of Northamptonshire," Quart. Journ. Geol. Soc., vol. xxix, p. 234.)

Just outside Weldon is a small roadside section in probably the highest beds of the Lincolnshire Oolite. It is an oolitic rock abounding in fossils, particularly gasteropods. Weldon as a source of Lincolnshire Oolite fossils will be better appreciated on reference to Mr. Hudleston's " Monograph of the British Jurassic Gasteropoda" (Palcontographical Society).

Weldon to Dene.-Between Weldon and Dene, in the valley. to the south of the road, a small section was examined, showing a very light coloured clay or marl resting directly upon a shelly

\footnotetext{
* The figures refer to diagram of comparative sections, p. $23^{\circ}$.
} 
limestone, aimost exactly like that seen a little previously near Weldon, thus fixing the position of this particular zone in this area. The clay represents the Upper Estuarine Beds of the Great Oolite.

Dene.-The section at Dene has been described in three of the works quoted in the list of references, but as none of these correlate the beds with others in the district, or quite agree with the observations of the Director, another is here given. The larger figures refer to the diagram of comparative sections, the smaller to Prof. Judd's description ("Geology of Rutland," Mem. Geol. Survey, pp. 101, 102).

ft. in.

$\begin{array}{lllllllll}3 . & \text { I. Marly limestones } & \ldots & \ldots & \ldots & \ldots & \ldots & \text { I to } 2 & 0 \text { ? }\end{array}$

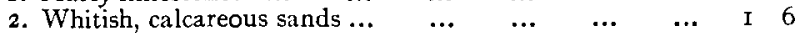

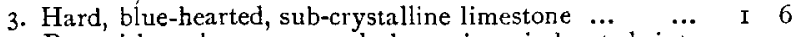

4. Brownish, calcareous sand, becoming indurated into

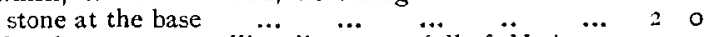

5. FIard and compact coralline limestone, full of Nerincea, $\begin{array}{llllllll}\text { with partings of clay } \ldots & \ldots & \ldots & \ldots & \ldots & 3 & \circ\end{array}$

6. Irregular bed of silicious concretions with mammilated surfaces below. This bed intensely hard; between its lamina are numerous plant remains; it appears to be the representative of the Collyweston Slate (Judd) $\ldots \quad \ldots \quad \ldots \quad \ldots \quad \ldots \quad \ldots \ldots$

4. 7. Irregularly stratified and false-bedded variegated sand ( 6 to $8 \mathrm{ft}$. - Judd)

In places almost passes into stone. Intimately connected with No. $3(6)$, and at one place rising

5. [Absent] into it a good deal, therefore thickness variable ... 6 o ?

6. 7. Light bluish sand, getting much whiter on exposure, with abundant vertical plant markings $\quad \ldots \quad \ldots \quad \ldots \quad 3 \quad$

7. 8. Dark carbonaceous, sandy clay, with masses of iron pyrites, and fragments of wood converted into iron $\begin{array}{llllllllll}\text { pyrites } \ldots & \ldots & \ldots & \ldots & \ldots & \ldots & \ldots & 5 & 0\end{array}$

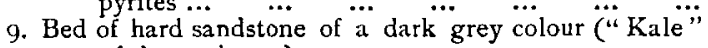

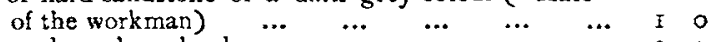

8. Io. Light coloured sandy clay $\ldots$...

9. II. Sandy ironstone (dug in a well), 3 to $4 \begin{array}{lllll} & \ldots & \ldots & \ldots & \end{array}$

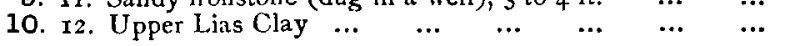

EvidENCES OF UNCONFORMITY.-In a set of beds characterized by an abundance of carbonaceous matter, and therefore of shallow water or estuarine origin, one need not be surprised at evidences of uncontormable succession anywhere in the series. The irregular junction between beds 7 and 8 at Corby and Weldon may be taken as evidence of denudation at those places. The horizontally or irregularly-bedded carbonaceous matter in No. 7 and the lower part of No. 6 may be looked upon as evidence of continued erosion not far away.

At Dene, erosion appears to have cut out the whole of Bed 5 and the upper part of Bed 6, as the junction between 4 and 6 is irregular; moreover, the lower part of No. 4 contains 
much carbonaceous matter more or less horizontally bedded, probably through the disturbance and re-deposition of the upper layers of No. 6, in which latter the carbonaceous matter is vertically disposed.

For these reasons and others connected with the examination of sections not included in the excursion, bed No. 4 has been placed with the Lincolnshire Oolite and not with the Lower Estuarine series as it is by Professor Judd and Mr. H. B. Woodward.

It is usually assumed that the Lincolnshire Oolite (Beds 2 to 4) was never deposited in the Northampton area, and that there was considerable denudation of the Lower Estuarine beds; the former assumption is probably correct, and the latter requires some modification. A typical section of the Estaurine beds near Northampton would be as below : *

6. I. White or bluish grey sands, with some argillaceous / $\begin{gathered}\mathrm{ft} \\ 3\end{gathered}$ matter with vertical plant markings, particularly to in lower part ... ... ... ... ... 4 o

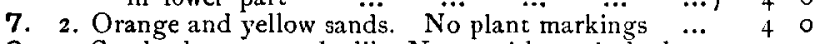

8. 3. Sands almost exactly like No. I, with vertical plant

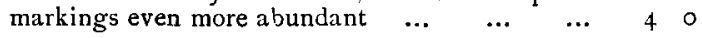

120

When we compare 1,2 , and 3 with beds 6,7 , and 8 at Corby, Weldon, and Dene, and see that collectively and individually they so nearly correspond in thickness and character (oxide of iron replacing iron pyrites in the middle one), it is scarcely possible to avoid the conclusion of their correspondence. It would thus appear that around Northampton denudation was not greater than at Dene.

Kirby Slate Quarries have not been in work for a great many years, but still the position of the slate beds relatively to the limestone series could be inferred from the nature of the excavation. Specimens of the slate itself were found where the working of it was formerly carried on. The slate usually consists of a single band of stone in the sandy beds (4), or it may, as at Collyweston, constitute the whole of that lithological division.

Kirby and Dene Lodge are the most southerly points at which slate has been worked for roofing material.

Gretton.-At Gretton the ironstone workings were examined, but here the Estuarine beds are absent, the ironstone either comes to the surface or is capped by Boulder Clay. The beautiful view across the Welland valley into Rutlandshire received appreciative attention.

Tea was provided at the Hatton Arms Hotel at Gretton,

*See "Excursion to Northamptonshire," Proc. Geol. Assoc., vol, xii, November, i8g (Diagram and page 184), also "The Oolitic Rocks at Stowe-nine-Churches," by Beeby Thompson, F.C.S., F.G.S., Journ. Northamptonshire Nat. Hist. Soc., $\mathrm{No} .48$, vol. vi, December, 18gr. 
CORBY.

COMPARATIVE SECTIONS.

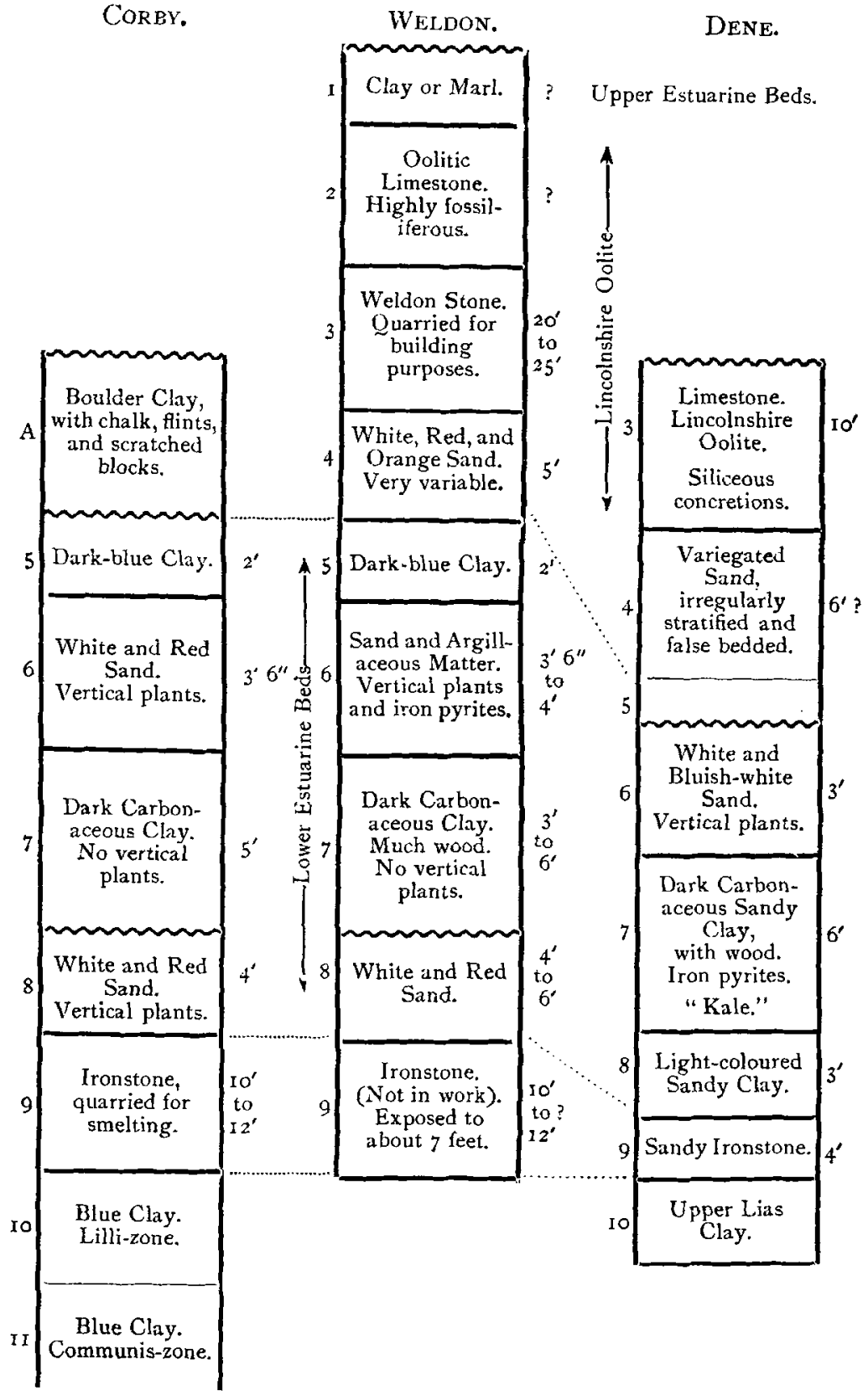


and most of the party departed by the train leaving Gretton at 6.28 p.m.

Geological Survey Map, Sheet No. 64.

REFERENCES.

I873. SHARP, Samuel.-" The Oolites of Northamptonshire." Quart. Gourn. Geol Soc., vol. xxix, p. 225.

1875. JuDd, John W.- "The Geology of Rutland," etc. Mem. Geol. Survey.

r886-96. Hunleston, W. H.- "Monograph of the British Jurassic Gasteropoda." Palceontographical Soc.

I887. Woodward, Horace B.- "The Geology of England and Wales." Second edition.

I893. iii. Mcm Geol. Surver.--"The Jurassic Rocks of Britain," vol.

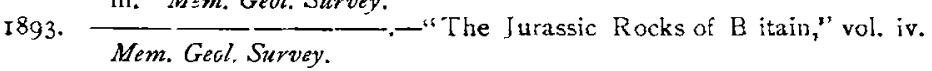

\section{EXCURSION TO BRITTANY.}

Whitsuntide, May i $8 \mathrm{Th}$ to $24 \mathrm{Th}$, I899.

Director : Charles Barrois, D.Sc., For. Memb. G.S.

Excursion Secretary: W. P. D. Stebuing, F.G.S.

(Report by Dr. Barrois, Translated by R. S. Herries.)

Thursday, May I8th.-The party started from London on May 17 th at 8.5 p.m., arriving at St. Malo at noon, when the ladies were all on deck; and the gentlemen were soon employed in making the acquaintance of the French custom house officers. However, in spite of the special facilities arranged for, the train was missed, and Dol was not reached till two hours after the appointed time, a delay which made it necessary to leave St. Marcan out of the programme.

Dol was known in Roman times as Campi Dolentes, but the name is evidently the Celtic word dol-low-lying, a dale. Dol is, indeed, a low-lying place, built on the old Post-Pliocene shore. The coast about Dol has undergone many changes, and from Dol to Mont St. Michel there is a low and marshy shore, where stand small isolated granitic hills, which have resisted marine denudation better than the surrounding Brioverian shales. The shales are covered by Recent and Quaternary beds, forming a great plain round Mont Dol, which, as well as Mont St. Michel, was an island before the eighth century. It has been calculated that the rate of deposit of sand and silt in this bay has been 16 million cubic feet a year. This marine deposit, which was, to a large extent, reclaimed from the sea by the industry of the inhabitants, was accumulated between the third and eighth centuries. It consists of fine, bluish grey, calcareous clays, with remains of marine shells, which are used for putting on the land. Below is

November, I899.] 